\title{
Protective Effect of the Castanha-de-cutia (Couepia edulis Prance) in Regards to Metabolic Illnesses and Its Socioeconomic Aspects: A Systematic Review
}

\author{
Adele Salomão-Oliveira ${ }^{1}$, Antonio Mário Galvão e Silva ${ }^{2} \&$ Rosany Piccolotto Carvalho ${ }^{3}$ \\ ${ }^{1}$ Multi-institutional Post-graduate Biotechnology Program, Federal University of Amazonas, Manaus, AM, \\ Brazil \\ ${ }^{2}$ Bionorte Post-graduate Network Biodiversity and Biotechnology Program, Federal University of Amazonas, \\ Manaus, AM, Brazil \\ ${ }^{3}$ Physiological Science Department, Federal University of Amazonas, Manaus, AM, Brazil \\ Correspondence: Adele Salomão-Oliveira, Multi-institutional Post-graduate Biotechnology Program, Federal \\ University of Amazonas (FUA), Manaus, AM, Brazil. E-mail: adelesalomao@gmail.com
}

Received: August 9, 2020

Accepted: October 14, $2020 \quad$ Online Published: November 15, 2020

doi:10.5539/jas.v12n12p120

URL: https://doi.org/10.5539/jas.v12n12p120

\begin{abstract}
The biodiversity of the Amazon region includes many oleaginous fruits, among them the Castanha-de-cutia, whose great potential is its almonds, which have about $16.6 \%$ protein and $73 \%$ oil. What is also remarkable is the exceptional amount of bioactive compounds in their chemical composition. This bibliographic review has the objective of arousing interest in the consumption of the Castanha-de-cutia almonds in order to improve quality of life. A systematic search was carried out for studies published between 1947 and 2016 that examined the physical-chemical characteristics, nutritional composition, bioactive functions and industrial potential of the almond from the Castanha-de-cutia. These studies included the use of this Amazonian fruit in the diet of traditional populations in the Amazon region. The presence of essential fatty acids, tocopherols, carotenoids and phenolic compounds strengthens the endogenous system, reducing oxidative stress and the risk of pathologies. The high content of monounsaturated fatty acids was also verified. This demonstrated exceptional nutritional value for the Castanha-de-cutia oil of Amazonian origin. The identification of the bioactive compounds of the Castanha-de-cutia almond is of fundamental importance as an alternative source of such compounds, since these desirable characteristics can be used in the prevention and treatment of metabolic diseases, as well as having great socioeconomic potential in the paint, food and pharmaceutical industries.
\end{abstract}

Keywords: Couepia edulis, Chrysobalanaceae, bioactive compounds, chronic non-communicable diseases, Amazon

\section{Introduction}

The Castanha-de-cutia (Couepia edulis Prance) (Figures 1 and 2), is a species of Amazonian origin and belongs to the family Chrysobalanaceae. It has a fibrous fruit, elongated, ovoid, dark brown in color, formed by a thick, smooth, hard, but spongy outer shell, which encloses a white almond with a dark, almost black, seed coat. The average weight of a fruit is $82 \mathrm{~g}$, and the average weight of an almond is $15.5 \mathrm{~g}$ (Pessoa et al., 2004). 


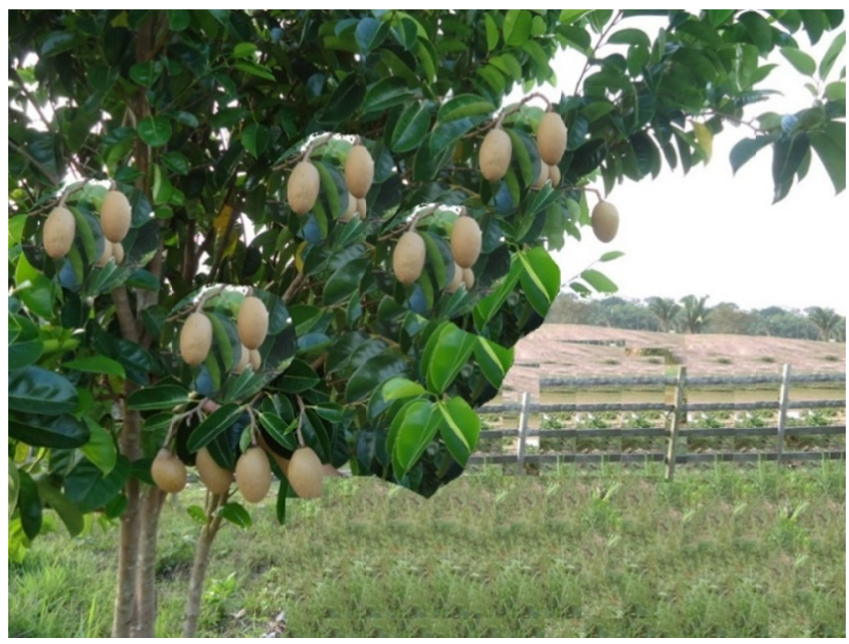

Figure 1. Castanha-de-cutia tree with oil from the Castanha-de-cutia almond

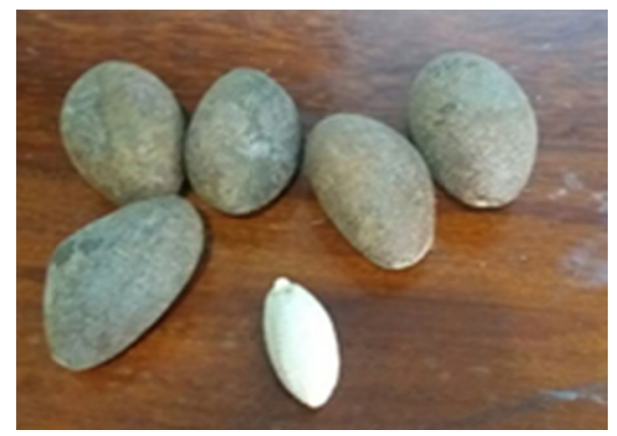

Figure 2. Amazonian oleaginous fruits of the Castanha-de-cutia tree

According to the Food and Agriculture Organization of the United Nations (FAO, 1987), the species is endemic to the central region of the Brazilian Amazon, between the municipalities of Tefé and Coari on the Amazon River, and can also be found on the Solimões, Trombetas, Ituí rivers, and in the municipality of Atalaia do Norte (Leandro et al., 2014).

The almond from the Castanha-de-cutia has biologically active components that produce beneficial health effects by correcting metabolic disorders, and therefore result in a reduction of the risk of chronic non-communicable diseases (NCDs) (Mahan \& Raymond, 2018).

In regards to the therapeutic properties of the oils found in the fruits from Castanha-de-cutia high levels of unsaturated fatty acids (UFA) stand out, and these are known for having protective effects against dyslipidemia (Falud et al., 2017; Santos et al., 2013; WHO, 2011), as long as they are associated with a balanced diet and a healthy lifestyle (FAO/WHO, 2003).

When compared to a low-fat and high-carbohydrate diet, a high monounsaturated fatty acid (MUFA) diet provides more favorable effects on triglyceride and high density lipoprotein HDL-c levels for the same degree of high cholesterol reduction (NCEP Step II). Studies show that diets containing MUFA in substitution for polyunsaturated fatty acids (PUFA) make low-density lipoprotein LDL-c less susceptible to oxidation, thereby inhibiting the atherogenic process (Falud et al., 2017).

As for the lipid composition in a diet, there is substantial evidence that $n-3$ of vegetable origin (nuts, flaxseed or canola oil) leads to anti-inflammatory effects similar to that caused by n-3 of marine origin (Salas-Salvadó et al., 2008). In several countries, the average fatty acid intake results in 10:1 to 20:1 $\omega-6: \omega-3$ ratios, with records of up to 50:1 occurring. Ratios of $2: 1$ and $3: 1$ have been recommended in the consumption of n-6:n-3 fatty acids, reflecting those found in the Japanese and Mediterranean diets, where the incidence of cardiovascular diseases has been historically low (Simpoulos, 2004). Figure 3 indicates the correct calculation of lipid proportions for a healthy and balanced daily diet of 2,500 kcal (IOM, 2005). 


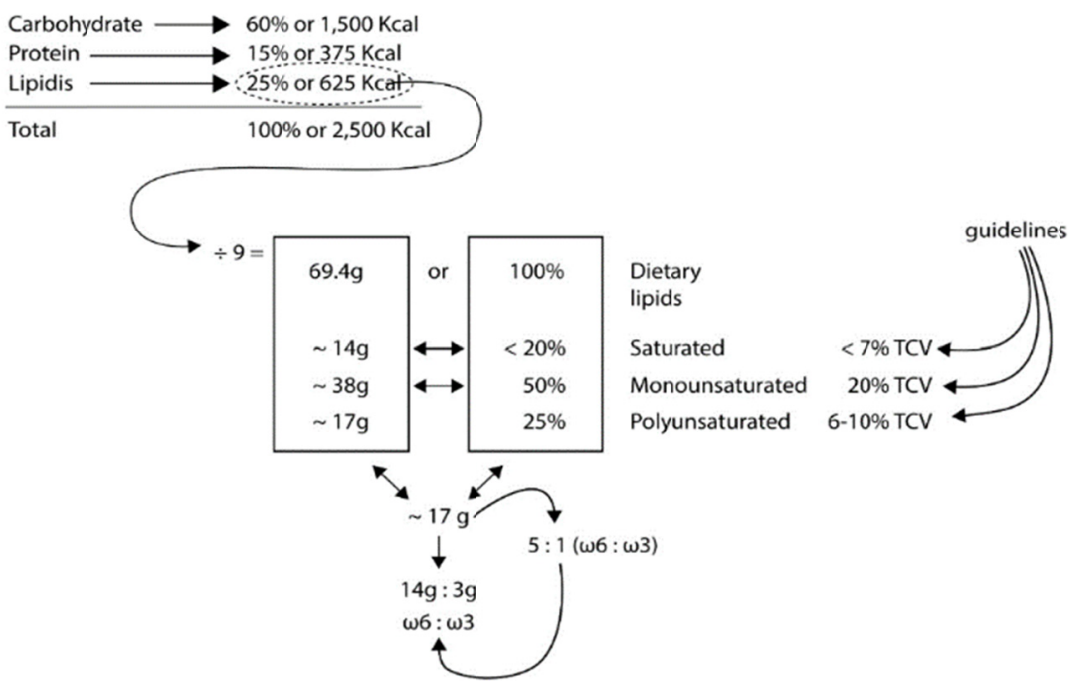

Figure 3. Example of a 2,500 kcal diet and the adequacy of the amounts of $\omega-6$ and $\omega-3$ in relation to the $5: 1$ ratio, respectively

Thus, functional foods are now a global research priority in order to elucidate the properties and effects that these products can have on health promotion and treatment of metabolic diseases (Alasalvar \& Shahidi, 2009; Arranz et al., 2008).

\section{Chemical Properties}

The centesimal composition of the residue or pomace of the oily seeds, expresses, in general, the percentage of the nutritional value present in $100 \mathrm{~g}$ of a sample as shown in Table 1.

Table 1. Centesimal composition of the Castanha-de-cutia almond, expressed in $\mathrm{g} 100^{-1}$

\begin{tabular}{lll}
\hline Composition (\%) & Costa e Jorge $(2011)^{*}$ & Cavalcante (1947) \\
\hline Moisture at $105^{\circ} \mathrm{C}$ & $9.24 \pm 0.08$ & 3.6 \\
Proteins & $7.34 \pm 0.12$ & 16.6 \\
Lipids & $68.89 \pm 0.09$ & 73 \\
Total Carbohydrates** & 1.15 & $\mathrm{ND}$ \\
Ashes & $2.17 \pm 0.01$ & 2.7 \\
Fiber $(\mathrm{g})$ & 11.21 & $\mathrm{ND}$ \\
Total Energetic Value (kcal) & 653.97 & $\mathrm{ND}$
\end{tabular}

Note. $*$ Values expressed in g. $100^{-1}$, determinations in triplicate with their means and respective standard deviations. The comparisons were made using the One-way ANOVA test followed by the Tukey post-test. ** Calculation by difference. ND: Not Determined.

This Amazonian oleaginous nut stands out for its high protein, lipid and fiber content (Leandro \& Yuyama, 2008; Pessoa \& Leeuwen, 2006). The high level of lipids of the Castanha-de-cutia almond is superior to other oleaginous nuts from the Amazon, as has been verified in studies which selected ten different edible nuts and investigated them for lipid composition, richness of PUFA, and obtained values that ranged from $43.71 \%$ for cashew nuts, to $66.71 \%$ for Brazil nuts (Venkatachalam \& Sathe, 2006).

The almonds from the Castanha-de-cutia are excellent nutritional sources, and $100 \mathrm{~g}$ of fruit have an average chemical composition of $18.6 \mathrm{~g}$ of protein; $254 \mathrm{mg}$ of calcium; $475 \mathrm{mg}$ of phosphorus; $4.4 \mathrm{mg}$ of iron and 0.67 $\mathrm{mg}$ of vitamin B2. Therefore, consumption of the Castanha-de-cutia almonds can provide important amounts of macronutrients and micronutrients needed for the human diet, in addition to being an excellent source of energy (Carvalho et al., 2008).

Some authors exalt the protein content of Castanha-de-cutia almonds and consider it as a meat analogue since it has around $17 \%$ protein, which is about five times the protein content of fresh bovine milk (Oliveira \& Vosti, 1997; Nascimento \& Romma, 1984). 
Dietary fiber has also been identified as an important component of a healthy diet and its consumption has been associated with a reduced risk of chronic diseases (WHO, 2013a). The Castanha-de-cutia almond has a high fiber content (11.2\%) (ANVISA, 2012); in fact, it is higher than the total dietary fiber content found in cashew nuts (3.7\%) and Brazil nuts (7.5\%) (TACO, 2011).

According to Table 2, Castanha-de-cutia almonds are good sources of unsaturated fatty acids (mono and polyunsaturated), which have been shown to reduce metabolic diseases, particularly those that present cardiovascular risks (Faludi et al., 2017; Alasalvar \& Shahidi, 2009).

Table 2. Average fatty acid composition (\%) of oils extracted from Brazil nuts

\begin{tabular}{llllll}
\hline Oil sample & n-6 & n-3 & Saturated & Monounsaturated & Polyunsaturated \\
\hline Brazil nut* & 20.5 & 0.04 & 15.1 & 24.6 & 20.6 \\
Cashew nut* & 8.3 & 0.1 & 8.3 & 25.5 & 8.4 \\
Castanha-de-cutia almond** & $12.39 \pm 0.03$ & 0.0 & $38.1 \pm 0.05$ & $40.39 \pm 0.02$ & $12.39 \pm 0.03$ \\
\hline
\end{tabular}

Note. *Alasalvar and Shahidi (2009). **Costa-Singh et al. (2012). Mean values \pm standard error of the mean of triplicate determinations.

It is known that lipids are, in one sense, important components of a healthy diet, and most of their harmful effects on health are related to their type and excessive consumption. A high intake of fats, especially saturated ones, has been linked to cardiovascular disorders, including atherosclerosis and thrombosis, as well as certain types of cancer and diabetes. Lipids also have biological importance in the human diet since they make up part of the group of macronutrients, and provide nutritional value to foods, thus making up the largest source of metabolic energy, essential fatty acids and fat-soluble vitamins. They are also associated with a reduction in the appearance of numerous metabolic diseases, when consumed in the recommended proportions (Faludi et al., 2017; Lottenberg, 2009).

The physico-chemical properties of the oil extracted from the Castanha-de-cutia almonds shown in Table 3 demonstrate that they are comparable to those of conventional oils of good quality, according to the recommendations for vegetable oils, with emphasis on the acidity index that is similar to that of refined oils, the maximum being 0.6mg KOH.g ${ }^{-1}$ (Codex, 2009; ANVISA, 2005).

Table 3. Physico-chemical characteristics of the oil from Castanha-de-cutia (Couepia edulis Prance) almonds, according to Costa-Singh et al. (2012), Cavalcanti (1947) and Pesce (1941)

\begin{tabular}{llll}
\hline Characteristics & Costa-Singh et al. (2012)* & Cavalcanti (1947) & Pesce (1941) \\
\hline Density $\left(15^{\circ}\right)$ & $\mathrm{ND}$ & 0.9955 & 0.942 \\
Acidity level & $0.69 \pm 0.01$ & $2.52 \%$ & $1.63 \%$ \\
Peroxide Index $\left(\mathrm{meq} \mathrm{kg}^{-1}\right)$ & $0.02 \pm 0.01$ & $\mathrm{ND}$ & $\mathrm{ND}$ \\
Thermo-sulfuric index (Tortelli) & $\mathrm{ND}$ & 37 & $\mathrm{ND}$ \\
Refractive index & $1.4763 \pm 0.0002$ & 1.466 & 1.496 \\
Melting point of fatty acids (initial) & $\mathrm{ND}$ & $32{ }^{\circ} \mathrm{C}$ & $\mathrm{ND}$ \\
Melting point of fatty acids (complete) & $\mathrm{ND}$ & $38{ }^{\circ} \mathrm{C}$ & $40.2{ }^{\circ} \mathrm{C}$ \\
Saponification index (mg KOH g & $-1)$ & 214 & 187.5 \\
Iodine Index & $187.73 \pm 0.89$ & 192.30 & 192.3 \\
Glycerin (\%) & $90.67 \pm 1.09$ & $\mathrm{ND}$ & 9.95 \\
Unsaponifiable (\%) & $\mathrm{ND}$ & $\mathrm{ND}$ & 1.3 \\
Acetyl Index & $0.38 \pm 0.01$ & $\mathrm{ND}$ & 139.9 \\
Ester Index & $\mathrm{ND}$ & $\mathrm{ND}$ & 184.24 \\
Crismer Index & $\mathrm{ND}$ & $\mathrm{ND}$ & 327.4 \\
Free fatty acids (\%) & $\mathrm{ND}$ & $\mathrm{ND}$ & $\mathrm{ND}$ \\
Oxidative stability (hours) & $0.35 \pm 0.01$ & $\mathrm{ND}$ & $\mathrm{ND}$ \\
\hline
\end{tabular}

Note. *Mean values \pm standard error of the mean of triplicate determinations. ND: Not Determined.

The proportions of the different saturated and unsaturated fatty acids in vegetable oils and fats vary according to the plants from which they were obtained, and there are also variations determined by the climatic conditions 
and type of soil in which they are grown. The thermal stability of oils depends on their chemical structure, and oils with saturated fatty acids are more stable than those with unsaturated ones (Faria et al., 2002).

The physicochemical properties of the oil extracted from the Castanha-de-cutia almonds present a high percentage of polyunsaturated fatty acids (PUFA), and one of the main aspects related to the protective effect of these compounds has been attributed, in part, to the presence of antioxidant compounds, among which total phenolic compounds and important levels of tocopherols stand out, especially the isomers $\alpha$-tocopherols and carotenoids (Costa-Singh et al., 2012) (Table 4). Thus, it is a naturally functional food that aids in the preservation of a healthy organism (Alasalvar \& Shahidi, 2009).

Table 4. Average concentration of $\alpha$-tocopherols, $\beta$-carotene, total phenolic compounds $(\mathrm{mg} / 100 \mathrm{~g}$ ) and total flavonoids $(\mathrm{mg} / 100 \mathrm{~g})$ of oils extracted from nuts

\begin{tabular}{lllll}
\hline Oil sample & $\begin{array}{l}\alpha \text {-tocopherols } \\
(\mu \mathrm{g} / \mathrm{g})^{*}\end{array}$ & $\begin{array}{l}\beta \text {-carotene } \\
(\mathrm{mg} / \mathrm{kg}) * * * *\end{array}$ & $\begin{array}{l}\text { Total phenolic compounds } \\
(\mathrm{mg} / 100 \mathrm{~g}))^{* *}\end{array}$ & $\begin{array}{l}\text { Total flavonoids } \\
(\mathrm{mg} / 100 \mathrm{~g}) * *\end{array}$ \\
\hline Brazil nut & 82.9 & 62.50 & 169.2 & 107.8 \\
Cashew nut & 3.6 & $\mathrm{ND}$ & 316.4 & 63.7 \\
Castanha-de-cutia Almond*** & $274.27 \pm 2.02$ & $\mathrm{ND}$ & $2.02\left(\mathrm{MG} \mathrm{GAE} \mathrm{g}^{-1}\right)$ & $\mathrm{ND}$ \\
\hline
\end{tabular}

Note. * Yang (2009); ** Yang et al. (2009); *** Costa-Singh et al. (2012); **** Miraliakbari and Shahidi (2008).

GAE: Gallic acid equivalents per gram. ND: Not Determined.

According to studies, it has been found that the chloroform/methanol extraction system provides oils with higher amounts of antioxidant components, which exhibit higher activities than extracts of oils extracted with hexane, and thus improve the stability of the oil and the potential for beneficial effects to health (Miraliakbari \& Shahidi, 2008).

Therefore, $\alpha$-tocopherol is the form of vitamin E with the highest biological activity (100\%) in the human body and prevents the oxidation of polyunsaturated fatty acids and lipid components of cells, followed by $\beta$-tocopherol (50\%), $\gamma$-tocopherol (26\%) and $\delta$-tocopherol (10\%) (Ramalho \& Jorge, 2006; Nogala-Kalucka et al., 2005). Thus, $\alpha$-tocopherol has the highest vitamin E activity, while $\gamma$ - and $\delta$-tocopherol have the highest antioxidant activity (Schmidt \& Pokorny, 2005).

As a result, the consumption of tocopherol plays an important role in improving immune function and in limiting the incidence and progression of chronic non-communicable diseases (NCDs) (Vignini et al., 2011).

The Castanha-de-cutia almond has a high content of $\alpha$-tocopherols when compared with the Brazil nut and the cashew nut. However, the cashew nut cannot be classified as a food source of alpha-tocopherol, as it does not contain more than 5\% of the Dietary Reference Intakes (DRI) value, Recommended Dietary Allowances (RDA) or Adequate Intake (AI) in a normal portion (IOM, 2000).

Carotenoids have pro-vitamin A activity, which are later transformed into retinol and antioxidant, reducing the risk of cancers and cardiovascular diseases, among other degenerative diseases (Dias et al., 2009). Among the carotenoids, $\alpha$-carotene is the most abundant in foods and one which has the highest vitamin A activity $(100 \%$ activity), while $\gamma$-carotene, $\alpha$-carotene, $\beta$-zeacarotene, $\beta$-cryptoxanthin and $\alpha$-criptoxanthin present only $50 \%$ of activity (Rodriguez-Amaya, 2008).

As with tocopherols, the increase in carotenoid levels in the body promotes the regulation of intercellular communication, the modulation of hormones and improves immune response, thus decreasing the risk of NCDs (Uenojo et al., 2007).

Phenolic compounds are widely found in plants and are a very diverse group of phytochemicals which are derived from phenylalanine and tyrosine, and provide oxidative stability (Uenojo et al., 2007). This mechanism of antioxidants in oleaginous fruits has a fundamental role in reducing lipid oxidation in tissues because, when incorporated into human food, antioxidants reduce the risk of developing chronic pathologies (Ramalho \& Jorge, 2006).

\section{Antioxidant Activity}

The Castanha-de-cutia almond possesses bioactive compounds, which are known for their functional action, for example, isoprenoids, phenolic compounds, carotenoids, tocopherols, polyunsaturated fatty acids, essential amino acids, fibers (Costa \& Jorge, 2011), and which are particularly attributed to its antioxidant activities (Huber et al., 2009; Silva et al., 2010). 
These antioxidant compounds exert various actions from the biological point of view, particularly in regards to the modulation of detoxification enzymes, stimulation of the immune system, reduction of platelet aggregation, antibacterial and antiviral activity, and contribute to the protection against the development of chronic diseases (Nery-Numa et al., 2018; Zimmermann \& Kirste, 2008).

Phenolic compounds are included in the category of free radical interrupters, and are very efficient in preventing self-oxidation (Balasundram et al., 2006). In addition, phenolic compounds can act as protectors and regenerators of primary antioxidants, such as ascorbic acid, tocopherol and $\beta$-carotene (Silva et al., 2010; Huber et al., 2009).

Tocopherols, carotenoids and phenolic compounds are bioactive compounds that have antioxidant activity in vitro and in vivo (Costa-Singh et al., 2012; Rodriguez-Amaya, 2008). However, the technology needed in order to make the consumption of these bioactive compounds possible must overcome some limiting factors to thus be effective. The main obstacles are that they are influenced by light, presence of $\mathrm{O}_{2}$, the physical and chemical properties of the food and the presence of possible initiators and catalysts of the reaction (Silva et al., 2010). Furthermore, the temperature in the antioxidant activity of tocopherols decreases when its concentration exceeds the optimum and may present a pro-oxidant effect, which can be more pronounced with the increase in temperature (between 40 and $60{ }^{\circ} \mathrm{C}$ ) (Evans \& Addis, 2002). However, above $40{ }^{\circ} \mathrm{C}$ the process of degradation of carotenoids and phenolic compounds begins (Rodrigues et al., 2013; Kechinski et al., 2010). Furthermore, studies report that consumers have less preference for synthetic antioxidants. Therefore, there is growing interest in obtaining antioxidant substances from plant products, which also present greater antioxidant activity than the synthetic products (Silva et al., 2010).

\section{Hypolipidemic Action}

Essential fatty acids, the $\mathrm{n}-6$ fatty acid series, derived from cis-linoleic acid (C18:2), and the $\mathrm{n}-3$ series, derived from $\alpha$-linolenic acid (C18:3) (Das, 2006), present in Amazonian oleaginous fruits (TACO, 2011; Costa-Singh et al., 2012), are compounds that give rise to other biologically active fatty acids, such as arachidonic, eicosapentaenoic (EPA; C20:5) and docosahexaenoic (DHA; C22:6) acids (Das, 2006). EPA and DHA are the two most important n-3 polyunsaturated fatty acids (greater than 18 carbons). In humans, the tissues that have the ability to biosynthesize EPA and DHA are the liver, the gonads and, to a lesser extent, the brain and adipose tissue, and do so from the precursor $\alpha$-linolenic acid, via enzymatic systems of elongation and desaturation of the hydrocarbon chain (Haag, 2003). Although these enzymes have a greater affinity for acids of the $n-3$ family, the conversion of $\alpha$-linolenic acid into DHA and EPA is strongly influenced by the levels of linoleic acid in the diet. An excess of this fatty acid can reduce the synthesis of $\alpha$-linolenic acid metabolites, such as eicosapentaenoic acid (Vaz et al., 2006).

Jenkins and co-workers carried out studies on the effect of almond consumption on the human lipid profile which examined 27 healthy or hyperlipidemic men and women, and these showed a reduction in the levels of total cholesterol and LDL-c and an increase in the levels of the cholesterol fraction of high density lipoproteins (HDL-c) when the intake of almonds per day was between 37 and $73 \mathrm{~g}$ (Jenkins et al., 2008).

Long-term randomized studies have confirmed the beneficial effects of regular consumption of nuts on the lipid profile in type 2 diabetic and non-diabetic patients, however, no improvement in their blood glucose levels was reported (Tapsell et al., 2004; Lovejoy et al., 2002).

Rajaram and co-workers evaluated the effect on the lipid profile in hyperlipidemic patients on diets enriched with nuts or fish for four weeks and found that, in the group of patients who consumed a diet containing $42.5 \mathrm{~g}$ of nuts per day, there was a greater reduction in total cholesterol levels. and LDL-c than in the control groups (without nuts and fish) and the fish group (113 g salmon, twice a week), while, in the group that received a fish diet, there was a reduction in plasma triglyceride levels and an increase in HDL-c levels (Rajaram et al., 2009).

\section{Cardioprotective Effect}

There are several nutritional strategies capable of maintaining cardiovascular health or reducing the risk of cardiovascular damage; among them is through the diet itself. Encouraging the consumption of healthy foods with adequate levels of $\omega-3, \omega-6$ and $\omega-9$ fatty acids, fibers, rational distribution of vitamins and minerals, reduction of sodium content and the practice of regular physical activity has been proven to be extremely beneficial (Faludi et al., 2017; Lottenberg et al., 2012). In addition, the substitution of foods rich in harmful fats for others with more adequate fatty acid profiles has been adopted as an effective practice for preventing cardiovascular disease (CVD) and diminishing the risk of coronary events (WHO, 2013a). 
CVD is one of the main causes of morbidity and mortality in the world, and multiple epidemiological studies associate the composition of the diet with its main risk factors (WHO, 2011). The early diagnosis and the reduction of elevated serum levels of triglycerides (TG), total cholesterol (TC) and LDL have contributed to a significant decrease in mortality and the incidence of cardiovascular disease (Faludi et al., 2017).

However, stroke is still the second leading cause of death in the world, and was responsible for 6.7 million deaths in 2012 (WHO, 2017). In Brazil, among the main causes of death, cerebrovascular diseases are the most common, followed by acute myocardial infarction (Brazil, 2017). The World Health Organization estimates that by 2030 strokes will still be the second leading cause of deaths in the world and responsible for $12.2 \%$ of the deaths predicted for the year (WHO, 2013b).

The Institute of Medicine recommends that diets have the lowest possible content of cholesterol, trans fatty acids and saturated fats, in view of the positive correlations of the intake of these types of lipids, related to elevated plasma LDL-c, and the increased risk cardiovascular diseases (IOM, 2005). However, since vegetable oils contain essential fatty acids and significant levels of other bioactive compounds, they contribute to the prevention of cardiovascular diseases through several mechanisms that can be attributed to their antioxidant effects that protect biomolecules from the action of free radicals (Santos et al., 2013; Lottenberg, 2009).

Currently, there are many types of drugs capable of controlling hyperlipidemia, however, this type of treatment, however efficient it may be, has a high cost and is not exempt from side effects. These side effects tend to be proportional to the size of the dose of the medication prescribed. In light of this fact, the Brazilian population has sought palliatives for such treatments, and many have included foods in their diet that have cardioprotective properties (Gonçalves et al., 2006).

Excessive consumption of oils containing saturated fatty acids with 12 to 16 carbon chains increases the concentration of low density lipoproteins (LDL-s) in the blood and increases the risk of cardiovascular diseases. Stearic acid is considered neutral in relation to its effect on blood lipids (Kris-Etherton et al., 2005), while monounsaturated and polyunsaturated fatty acids tend to have an inverse relationship with the incidence of coronary heart disease (Binkoski et al., 2005).

The consumption of monounsaturated vegetable oils, rich in oleic acid (C18:1, n-9) has also been recommended because these oils are also associated with a reduction in the incidence of heart disease. Although not considered an essential fatty acid, oleic acid has been shown to have a neutral effect on cholesterolemia. However, diets rich in oleic acid have been observed to increase the level of the cholesterol fraction of high density lipoproteins (HDL-c) and reduce the level of the cholesterol fraction of low density lipoproteins (LDL-c) (Santos et al., 2013).

Epidemiological studies have demonstrated distinct relationships between the type of fat ingested and changes in blood pressure. Changes in the proportions of fats, with a reduction in saturated fatty acids (SFA) and an increase in MUFA may contribute to a reduction in blood pressure and possibly play a relevant role in lowering the risk of coronary artery disease. However, this beneficial effect can be reversed if the total consumption of fat is excessive (Santos et al., 2013; Mente et al., 2009; Rasmussen et al., 2006).

\section{Anti-inflammatory Properties}

Studies have found that metabolism and immunity are interdependent and that excessive food intake contributes to a greater risk of inflammatory diseases and, therefore, adequate nutrient consumption is essential to preserve immune function (Lottenberg et al., 2012). Thus, obesity, diabetes mellitus and dyslipidemia are pro-atherogenic conditions (Wellen \& Hotamisligil, 2005).

These NCDs favor the development of atherosclerosis, which is a chronic inflammatory disease of multifactorial origin that occurs in response to endothelial aggression and consequently induces the onset of chronic inflammatory processes that are accompanied by the absence of vasodilator and antithrombotic factors and an increase in vasoconstrictor and prothrombotic products, which characterizes endothelial dysfunction (Thomazella et al., 2011).

Regarding the specific effect of fatty acids on inflammation, several studies have found a strong association between trans and saturated fat intake and the synthesis of inflammatory biomarkers (Baer et al., 2004). An epidemiological study of overweight individuals showed an increase in interleukin-6 with diets high in saturated fat (Lopez-Garcia et al., 2005). The danger in high consumption of saturated fatty acids is related to lipotoxicity, which affects several organs and increases the risk of diabetes and cardiovascular diseases as a result of its strong relationship with inflammation and insulin resistance (Garbarino \& Sturley, 2009). 
Therefore, unsaturated fatty acids have been shown to have protective effects in such disorders, since studies have shown their ability to modulate monocytes in the stimulation of epithelial cells, which contributes to their protective effects against chronic inflammatory disorders (Luu et al., 2007).

Studies have shown that consumption of MUFA is related to improvements in endothelial function and monocytic adhesion, in addition to reductions in inflammatory markers and platelet aggregation, thereby providing protection against thrombogenesis and oxidative stress (Santos et al., 2013; Delgado-Lista et al., 2011).

In view of the mechanisms involved in the formation of atherosclerotic plaque, the main objectives of therapies are the control of dyslipidemia and inflammation, in addition to protecting the vascular endothelium. Thus, the treatment of atherosclerosis requires a broad and simultaneous approach in relation to all risk factors, prioritizing initially a change in lifestyle that includes nutritional therapy (Lorente-Cebrián et al., 2013). Epidemiological studies have reported that supplementation with polyunsaturated fatty acids (PUFA) would have an inverse correlation with the incidence of atherosclerosis, limiting the inflammatory process, the progression of atheromatous plaques and reducing vulnerability to rupture phenomena, with possible clinical benefits (Moreno \& Mitjavila, 2003).

Furthermore, oil from Castanha-de-cutia almond has, in its chemical composition, fatty acids with a higher percentage of unsaturated fatty acids and relevant levels of bioactive compounds, with emphasis on phenolic compounds and $\alpha$-tocopherols, which are associated with a reduction in the risk of a variety of chronic diseases due to the oil's anti-inflammatory, antimicrobial, anticarcinogenic, antiallergic and antiviral properties (Costa-Singh et al., 2012).

\section{Type 2 Diabetes Melitus (DM 2)}

DM 2 is an important and growing health problem in all countries, regardless of their level of development. It is estimated that $46 \%$ of adult diabetes cases are undiagnosed and that $83.8 \%$ of all undiagnosed diabetes cases are in developing countries (ADA, 2017). The World Health Organization (WHO) estimates that high blood sugar is the third most important factor in the cause of premature mortality, surpassed only by increased blood pressure and tobacco use (ADA, 2013).

Diabetes is also associated with higher rates of hospitalizations and greater use of health services, due to a higher incidence of cardiovascular and cerebrovascular diseases, blindness, kidney failure and non-traumatic lower limb amputations, thus one can predict the burden that this increase in diabetes will represent in the coming years for the health systems of all countries, regardless of their level of economic development (ADA, 2015).

Most countries spend between 5 and $20 \%$ of their total health expenditure on treating diabetes. With this high cost, diabetes is an important challenge for health systems and an obstacle to sustainable economic development (ADA, 2017).

Furthermore, most individuals with DM2 suffer from obesity, high blood pressure and dyslipidemia, and interventions by health services must address these multiple metabolic abnormalities in order to reduce mortality (DSBD 2017-2018). Randomized, controlled clinical studies have shown that individuals can decrease their rate of development of diabetes via interventions in their lifestyle (ADA, 2017; DPP, 2002).

The consumption of bioactive compounds is associated with the prevention and control of NCDs, and these compounds, which are present in the Castanha-de-cutia almond, have exceptional biological properties. These include antioxidant, antimicrobial, anti-inflammatory properties and vasodilatory actions, which are all important for protection against the effects of type 2 DM (Costa-Singh et al., 2012). Thus, an increase in the levels of polyphenols and carotenoids (pro vitamin A) in the diet can have profound effects on inflammatory suppression and on the reduction of oxidative damage in the islets of Langerhans. Inverse correlations between insulin resistance and dietary intake of fat-soluble antioxidant vitamins were found in research conducted with individuals, with an average age of 47 years, at various levels of insulin resistance and normal glucose tolerance (Luna \& Costa, 2013).

Among the parameters for this metabolic syndrome (MS), insulin resistance is undoubtedly the primary factor for its occurrence and the individual components that define MS include dyslipidemia (elevated triglycerides and LDL-cholesterol), impaired fasting glucose, high blood pressure and abdominal obesity (Alberti et al., 2009).

Human studies demonstrate that short-term interventions, such as replacing PUFA with MUFA, or the simple increase in MUFA consumption, can lead to improvements in insulin resistance, when associated with fiber consumption and a healthy lifestyle (Lopez et al., 2011; Paniagua et al., 2007; Xiao et al., 2006). 
Studies regarding Mediterranean diets, in which nuts are regularly consumed, demonstrated an association between Mediterranean diet scores and the risk of MS. The diet was inversely associated with abdominal circumference, systolic blood pressure and triglycerides, and in a direct manner associated with HDLcholesterol, insulin resistance and fasting glucose (Kesse-Guyot et al., 2013).

Thus, the inclusion of nuts in nutritionally balanced diets has significant and consistent protection in relation to the occurrence of the main chronic diseases, and is recommended in the Dietary Guidelines for Americans (DeSalvo et al., 2016) and also adopted by Brazilian Guidelines (DSBD, 2017; Faludi et al., 2017; Santos et al., 2013).

\section{Industrial Potential}

The Castanha-de-cutia tree adapts well in the poor, clayey soils of the upland rainforest, including areas that normally flood. In Manaus, Brazil, this species blooms between February and November and bears fruit between February and August (Leandro et al., 2014; Pessoa et al., 2004).

This oleaginous Amazonian fruit grows well in a monoculture system and, so far, there has been no news of pests or diseases. In fertile soils, an adult tree can produce more than 2,400 fruits, equivalent to $200 \mathrm{~kg}$ (FAO, 1987), which equates to $38 \mathrm{~kg}$ of almonds or $28 \mathrm{~kg}$ of oil. In a plantation with 100 trees/ha, the equivalent of 20 $\mathrm{t} / \mathrm{ha} /$ year of fruit can be produced (3.8 $\mathrm{t}$ of almonds or $2.8 \mathrm{t}$ of oil) (Pessoa \& Leeuwen, 2006).

One study described more than 120 oily seed species from the Amazon region and stated that Couepia edulis is undoubtedly one of the most interesting seeds in this region, both for its percentage in oil and for the quality of its oil, which is very clear, edible and easily refined (Pesce, 1941).Thus, the oil extracted from the almonds is clear, odorless, can be used for cooking. This oil of this nut of Amazonian origin is classified as a curing agent, with great prominence in the industry of paints, varnishes, lacquers, linoleum, can be used for waterproofing leather, and in all branches of printing and similar industries (Leandro and Yuyama, 2008; Pessoa and Leeuwen, 2006) and is similar to China wood oil (Aleurites sp.) and oiticica oil (Licaniarigida Benth) in terms of specific weight and its high refractive index (Cavalcante, 1947).

The almonds of this Amazonian species can be eaten roasted, or mixed with manioc flour. They taste similar to the Brazil nut (Bertholletia excelsa), though with a slightly softer texture (Pessoa et al., 2004), and in combination with other cereals and fruits they produce countless processed snacks that are popular with consumers (Carvalho et al., 2008).

\section{Conclusions}

The bioactive properties of Castanha-de-cutia almonds include high levels of PUFAs, with emphasis on MUFAs, proteins, fibers, micronutrients and antioxidant compounds and cause stimulation of the immune system in the protection against metabolic diseases, which makes them comparable to regular almonds (Prunus dulcis) which are widely traded on the national and international markets. Castanha-de-cutia almonds are also promising for the sustainable socioeconomic development (bioeconomy) of the Amazonian population. Therefore, this oleaginous Amazonian fruit is promising for the production of foods with special health purposes, industry, as well as the pharmaceutical industry.

\section{Acknowledgements}

The authors thank the Federal University of Amazonas and the support provided by FAPEAM with the publication fee paid with PAPAC resource.

\section{References}

ADA (American Diabetes Association). (2013). Diagnosis and classification of diabetes mellitus. Diabetes Care, 36(Suppl. 1), S67-S74. https://doi.org/10.2337/dc13-S067

ADA (American Diabetes Association). (2015). Clinical Practice Recommendations. Diabetes Care, 38(Suppl. 1), S70-S76. https://doi.org/10.2337/dc15-S014

ADA (American Diabetes Association). (2017). Prevention or delay of type 2 diabetes. Diabetes Care, 40(Suppl. 1), S44-S47. https://doi.org/10.2337/dc17-S008

Alasalvar, C., \& Shahidi, F. (2009). Natural antioxidants in tree nuts. Eur. J. Lipid. Sci. Technol., 111(11), 1056-1062. https://doi.org/10.1002/ejlt.200900098

Alberti, K. G., Eckel, R. H., Grundy, S. M., Zimmet, P. Z., Cleeman, J. I., Donato, K. A., ... Smith, S. C. (2009). Harmonizing the metabolic syndrome: A joint interim statement of the International Diabetes Federation Task Force on Epidemiology and Prevention; National Heart, Lung, and Blood Institute; American Heart 
Association; World Heart Federation; International Atherosclerosis Society; and International Association for the Study of Obesity. Circulation, 120(16), 1640-1645. https://doi.org/10.1161/CIRCULATIONAHA. 109.192644

ANVISA (Agência Nacional de Vigilância Sanitária). (2005). Resolução-RDC n. 270, de 22 de setembro de 2005. Aprova o regulamento técnico para óleos vegetais, gorduras vegetais e creme vegetal. Brasília, DF.

ANVISA (Agência Nacional de Vigilância Sanitária). (2012). Resolução-RDC n. 54, de 12 de novembro de 2012. Dispõe sobre o Regulamento Técnico sobre Informação Nutricional Complementar. Retrieved from http://bvsms.saude.gov.br/bvs/saudelegis/anvisa/2012/anexo/anexo_rdc0054_12_11_2012.pdf

Arranz, S., Pérez-Jiménez J., \& Saura-Calixto, F. (2008). Antioxidant capacity of walnut (Juglans regia L.): contribution of oil and defatted matter. European Food Research and Technology, 227(2), 425-431. https://doi.org/10.1007/s00217-007-0737-2

Baer, D. J., Judd, J. T., Clevidence, B. A., \& Tracy, R. P. (2004). Dietary fatty acids affect plasma markers of inflammation in healthy men fed controlled diets: A randomized cross over study. Am J Clin Nutr, 79(6), 969-973. https://doi.org/10.1093/ajcn/79.6.969

Balasundram, N., Sundram, K., \& Samman, S. (2006). Phenolic compounds in plants and agri-industrial by-products: Antioxidant activity, occurrence, and potential uses. Food Chemistry, 99(1), 191-203. https://doi.org/10.1016/j.foodchem.2005.07.042

Binkoski, A. E., Kris-Etherton P. M., Wilson T. A., Mountain M. L., \& Nicolosi, R. J. (2005). Balance of unsaturated fatty acids is important to a cholesterol-lowering diet: Comparison of mid-oleic sunflower oil and olive oil on cardiovascular disease risk factors. Journal of the American Dietetic Association, 105(7), 1080-1086. https://doi.org/10.1016/j.jada.2005.04.009

Brazil, Ministério da Saúde. (2017). Secretaria de Vigilância em Saúde, Departamento de Vigilância de Doenças e Agravos não Transmissíveis e Promoção da Saúde, Vigitel, Brasil. Vigilância de fatores de risco e proteção para doenças crônicas por inquérito telefônico: Estimativas sobre frequência e distribuição sociodemográfica de fatores de risco e proteção para doenças crônicas nas capitais dos 26 estados brasileiros e no Distrito Federal em 2016. Brasília: MS.

Carvalho, M. G., Costa, J. M. C., Souza, V. A. B., \& Maia, G. A. (2008). Evaluation of some physical and nutritional parameters of almonds of chichá, sapucaia and castanha-do-gurguéia. Revista Ciência Agronômica, 39(4), 517-523.

Cavalcante, M. C. P. B. (1947). Óleo de Castanha de Cotia: Novo óleo secativo. Ministério do Trabalho, Indústria e Comércio, Instituto Nacional de tecnologia, Rio de Janeiro, Brazil.

Codex Alimentarius Commission. (2009). Codex-Stan 210: Codex standard for named vegetable oils. Roma: FAO/WHO Food Standards.

Costa, T., \& Jorge, N. (2011). Beneficial Bioactive Compounds Present in Nuts and Walnuts. UNOPAR. Cient Ciênc Biol Saúde, 13(3), 195-203.

Costa-Singh, T., Bitencourt T. B., \& Jorge, N. (2012). Caracterização e compostos bioativos do óleo da castanha-de-cutia (Couepia edulis). Rev Inst AdolfoLutz, 71(1), 61-68.

Das, U. N. (2006). Essential fatty acids: Biochemistry, physiology and pathology. Biotechnology Journal, 1(4), 420-439. https://doi.org/10.1002/biot.200600012

De Salvo, K. B., Olson R., \& Casavale, K. O. (2016). Dietary Guidelines for Americans. JAMA, 315(5), $457-458$. https://doi.org/10.1001/jama.2015.18396

Delgado-Lista, J., Garcia-Rios, A., Perez-Martinez, P., Lopez-Miranda, J., \& Perez-Jimenez, F. (2011). Olive oil and haemostasis: Platelet function, thrombogenesis and fibrinolysis. Curr Pharm Des., 17(8), 778-785. https://doi.org/10.2174/138161211795428876

DPP (Diabetes Prevention Program). (2002). Research Group. The Diabetes Prevention Program (DPP): description of lifestyle intervention. Diabetes Care, 25 (12), 2165-2171. Dias, M. G., Camões M. F. G. F. C., \& Oliveira, L. (2009). Carotenoids in traditional Portuguese fruits and vegetables. Food Chemistry, 113(3), 808-815. https://doi.org/10.1016/j.foodchem.2008.08.002

DSBD. (2017). Diretrizes da Sociedade Brasileira de Diabetes 2017-2018. São Paulo: Editora Clannad. Retrieved from https://www.diabetes.org.br/profissionais/images/2017/diretrizes/diretrizes-sbd-2017-2018.pdf 
Evans, J. C., Kodali D. R., \& Addis, P. B. (2002). Optimal tocopherol concentrations to inhibit soybean oil oxidation. Journal of the American Oil Chemists' Society, 79, 47-51. https://doi.org/10.1007/s11746-0020433-6

Faludi, A. A., Izar, M. C. O., Saraiva, J. F. K., Chacra, A. P. M., Bianco, H. T., Neto, A. A., ... Salgado Filho, W. (2017). Atualização da Diretriz Brasileira de Dislipidemias e Prevenção da Aterosclerose. Arq. Bras. Cardiol, 109(2, Suppl. 1), 1-76. https://doi.org/10.5935/abc.20170121

FAO (Food and Agriculture Organization of the United Nations). (1987). Especies florestales productoras de frutas y otros alimentos. Ejemplos de America Latina, Organizacion de las Naciones Unidas para la Agricultura e la Alimentación, Roma. Retrieved from http://www.fao.org/3/a-an785s.pdf

FAO/WHO (Food and Agriculture Organization of the United Nations/World Health Organization). (2003). Relatório pericial sobre dieta alimentar, nutrição e prevenção de doenças crônicas. Genebra, Suíça. Retrieved from https:/www.who.int/nutrition/publications/pressrelease32_pt.pdf

Faria, E. A., Leles, M. I. G., Ionashiro, M., Zuppa, T. O., \& Antoniosi Filho, N. R. (2002). Estudo da estabilidade térmica de óleos e gorduras vegetais por TG/DTG E DTA. Eclet. Quím., 27, 00-00. https://doi.org/10.1590/ S0100-46702002000100010

Garbarino, J., \& Sturley, S. L. (2009). Saturated with fat: new perspectives on lipotoxicity. Curr Opin Clin Nutr Metab Care, 12(2), 110-116. https://doi.org/10.1097/MCO.0b013e32832182ee

Gonçalves, M. C. R., Diniz, M. F. F. M., Borba, J. D. C., Nunes, X. P., \& Barbosa-Filho, J. M. (2006). Eggplant (Solanum melongena L.) - Myth or reality in the fight against the dislipidemy? Revista Brasileira de Farmacognosia, 16(2), 252-257. https://doi.org/10.1590/S0102-695X2006000200020

Haag, M. (2003). Essential Fatty Acids and the Brain. The Canadian Journal of Psychiatry, 48(3), $195-203$. https://doi.org/10.1177/070674370304800308

Huber, L. S., Hoffmann-Ribani, R., \& Rodriguez-Amaya, D. B. (2009). Quantitative variation in Brazilian vegetable sources of flavonols and flavones. Food Chemistry, 113(4), 1278-1282. https://doi.org/10.1016/ j.foodchem.2008.08.030

IOM (Institute of Medicine). (2000). Dietary Reference Intakes for Vitamin C, Vitamin E, Selenium, and Carotenoids. Washington (DC): National Academy Press.

IOM (Institute of Medicine). (2005). Dietary reference intakes for energy, carbohydrate, fiber, fat, fatty acids, cholesterol, protein, and amino acids (macronutrients). Washington: National Academy Press.

Jenkins, D. J., Kendall, C. W., Marchie, A., Josse, A. R., Nguyen, T. H., Faulkner, D. A., ... Blumberg, J. (2008). Almonds reduce biomarkers of lipid peroxidation in older hyperlipidemic subjects. The Journal of Nutrition, 138(5), 908- 913. https://doi.org/10.1093/jn/138.5.908

Kechinski, C. P., Guimarães, P. V. R., Noreña, C. P. Z., Tessaro, I. C., \& Marczak, L. D. F. (2010). Degradation Kinetics of Anthocyaninin Blueberry Juice during Thermal Treatment. Journal of Food Science, 75(2), C173-C176. https://doi.org/10.1111/j.1750-3841.2009.01479.x

Kesse-Guyot, E., Ahluwalia, N., Lassale, C., Hercberg, S., Fezeu, L., \& Lairon, D. (2013). Adherence to Mediterranean diet reduces the risk of metabolic syndrome: A 6-year prospective study. Nutr Metab Cardiovasc Dis., 23(7). 677-683. https://doi.org/10.1016/j.numecd.2012.02.005

King, J. C., Blumberg, J., Ingwersen, L., Jenab, M., \& Tucker, K. L. (2008). Tree nuts and peanuts as components of a healthy diet. The Journal of Nutrition, 138(9), S1736-S1740. https://doi.org/ 10.1093/jn/138.9.1736S.

Kris-Etherton, P. M., Griel, A. E., Psota, T. L., Gebauer, S. K., Zhang, J., \& Etherton, T. D. (2005). Dietary stearic acid and risk of cardiovascular disease: intake, sources, digestion, and absorption. Lipids, 40(12), 1193-1200. https://doi.org/10.1007/s11745-005-1485-y

Leandro, R. C., \& Yuyama, K. (2008). Enraizamento de estacas de castanha-de-cutia com uso de ácido indolbutírico. Acta Amazônica, 38(4), 597-602. https://doi.org/10.1590/S0044-59672008000400001

Leandro, R. C., Coelho, E. C. S., \& Feitosa, I. L. (2014). Efeito de diferentes tratamentos na germinação de castanha-de-cutia (Couepia edulis Prance), visando a produção de mudas, no estado do Amazonas. Scientia Amazonia, 3(2), 1-5. 
Lopez, S., Bermudez, B., Ortega, A., Varela, L. M., Pacheco, Y. M., Villar, J., .. Muriana, F. J. (2011). Effects of meals rich in either monounsaturated or saturated fat on lipid concentrations and on insulin secretion and action in subjects with high fastin $\mathrm{g}$ triglyceride concentrations. Am. J. Clin. Nutr., 93(3), 494-499. https://doi.org/10.3945/ajcn.110.003251

Lopez-Garcia, E., Schulze, M. B., Meigs, J. B., Manson, J. E., Rifai, N., Stampfer, M. J., ... Hu, F. B. (2005). Consumption of trans fatty acids is related to plasma biomarkers of inflammation and endothelial dysfunction. J. Nutr., 135(3), 562-566. https://doi.org/10.1093/jn/135.3.562

Lorente-Cebrián, S., Costa, A. G., Navas-Carretero, S., Zabala, M., Martínez, J. A., \& Moreno-Aliaga, M. J. (2013). Role of omega-3 fatty acids in obesity, metabolic syndrome, and cardiovascular diseases: a review of the evidence. J. Physiol. Biochem., 69(3), 633-651. https://doi.org/10.1007/s13105-013-0265-4

Lottenberg, A. M. P. (2009). Importance of the dietary fat on the prevention and control of metabolic disturbances and cardiovascular disease. Arq. Bras. Endocrinol. Metab., 53(5), 595-607. https://doi.org/ 10.1590/S0004-27302009000500012

Lottenberg, A. M., Afonso, M. S., Lavrador, M. S., Machado, R. M., \& Nakandakare, E. R. (2012). The role of dietary fatty acids in the pathology of metabolic syndrome. J. Nutr. Biochem., 23(9), 1027-1040. https://doi.org/10.1016/j.jnutbio.2012.03.004

Lovejoy, J. C., Most, M. M., Lefevre, M., Greenway, F. L., \& Rood, J. C. (2002). Effect of diets enriched in almonds on insulin action and serum lipids in adults with normal glucose tolerance or type 2 diabetes. American Journal of Clinical Nutrition, 76(5), 1000-1006. https://doi.org/10.1093/ajcn/76.5.1000

Luna, R. C. P., \& Costa, M. J. C. (2013). Relation between vitamin A and glycemic control: metabolic aspects and perspectives in the prevention of dysglycemia. Rev Bras Nutr Clin., 28(2), 141-148. https://doi.org/ $10.1177 / 0884533612470466$

Luu, N. T., Madden, J., Calder, P. C., Grimble, R. F., Shearman, C. P., Chan, T., ... Nash, G. B. (2007). Dietary supplementation with fish oil modifies the ability of human monocytes to induce an inflammatory response. J. Nutr., 137(12), 2769-2774. https://doi.org/10.1093/jn/137.12.2769

Mahan, L. K., \& Raymond, J. L. (2018). Krause Alimentos, Nutrição e Dietoterapia (14th ed.). Elsevier.

Mente, A., Koning, L., Shannon, H. S., \& Anand, S. S. (2009). A systematic review of the evidence supporting a causal link between dietary factors and coronary heart disease. Arch Intern Med., 169(7), 659-669. https://doi.org/10.1001/archinternmed.2009.38

Miraliakbari, H., \& Shahidi, F. (2008). Antioxidant activity of minor components of tree nut oils. Food Chemistry, 111(2), 421-427. https://doi.org/10.1016/j.foodchem.2008.04.008

Moreno, J. J., \& Mitjavila, M. T. (2003). The degree of unsaturation of dietary fatty acids and the development of atherosclerosis. Journal of Nutritional Biochemistry, 14(4), 182-195. https://doi.org/10.1016/s0955-2863 (02) 00294-2

Nascimento, C. N., \& Romma, A. (1984). Amazônia: meio ambiente e tecnologia agrícola. Belém-PA, Brazil: Embrapa-CPATU. Retrieved from https:/www.infoteca.cnptia.embrapa.br/infoteca/handle/doc/386339

Neri-Numa, I. A., Soriano Sancho, R. A., Pereira, A. P. A., \& Pastore, G. M. (2018). Small Brazilian wild fruits: Nutrients, bioactive compounds, health-promotion properties and commercial interest. Food Res Int., 103, 345-360. https://doi.org/10.1016/ j.foodres.2017.10.053

Nogala-Kalucka, M., Korczak, J., Dratwia, M., Lampsrt-Szczapa, E., Siger, A., \& Buchowski, M. (2005). Changes in antioxidant activity and free radical scavenging potential of rosemary extract and tocopherols in isolated rapeseed oil triacylgliycerols during accelerated tests. Food Chem., 93(2), 227-235. https://doi.org/ 10.1016/j.foodchem.2004.09.021

Oliveira, S. J. M., \& Vosti, A. S. (1997). Aspectos econômicos de sistemas agroflorestais em Ouro Preto do Oeste, Rondônia (Circular Técnica, 29). Porto Velho: EMBRAPA-CPAF. Retrieved from https:/www.infoteca. cnptia.embrapa.br/infoteca/bitstream/doc/700861/1/CPAFRODOCUMENTOS29ASPECTOSECONOMICO SDESISTEMAAGROFLORESTAISEMOUROPRETODOOESTERONDON.pdf

Paniagua, J. A., La Sacristana, A. G., Sánchez, E., Romero, I., Vidal-Puig, A., Berral, F. J., ... Pérez-Jiménez, F. (2007). A MUFA-rich diet improves posprandial glucose, lipid and GLP-1 responses in insulin-resistant subjects. J. Am. Coll. Nutr., 26(5), 434-444. https://doi.org/10.1080/07315724.2007.10719633

Pesce, C. (1941). Oleaginosas da Amazônia. Revista Veterinária. Belém-PA, Brazil. 
Pessoa, J. D. C., \& Leeuwen, J. V. (2006). Development of a shelling method to recover whole kernels of the cutia nut (Couepia edulis). Revista Brasileira de Fruticultura, 28(2), 236-239. https://doi.org/10.1590/ S0100-29452006000200018

Pessoa, J. D. C., Assis, O. B. G., \& Braz, D. C. (2004). Caracterização morfomecânica para beneficiamento do fruto da castanha-de-cutia (Couepia edulis). Rev. Bras. Frutic., 26(1), 103-106. https://doi.org/10.1590/ S0100-29452004000100028

Rajaram, S., Haddad, E. H., Mejia, A., \& Sabaté, J. (2009). Walnuts and fatty fish influence different serum lipid fractions in normal to mildly hyperlipidemic individuals: a randomized controlled study. Journal of Clinical Nutrition, 89(5), 1657S-1663S. https://doi.org/10.3945/ajcn.2009.26736S

Ramalho, V. C., \& Jorge, N. (2006). Antioxidantes utilizados em óleos, gorduras e alimentos gordurosos. Quím Nova, 29(4), 755-760. https://doi.org/10.1590/S0100-40422006000400023

Rasmussen, B. M., Vessby, B., Uusitupa, M., Berglund, L., Pedersen, E., Riccardi, G., ... Hermansen, K. (2006). KANWU Study Group. Effects of dietary saturated, monounsaturated, and n-3 fatty acids on blood pressure in healthy subjects. Am. J. Clin. Nutr., 83(2), 221-226. https://doi.org/10.1093/ajcn/83.2.221

Rodrigues, M. L., Souza, A. R. M., Lima, J. C. R., Moura, C. J., \& Geraldine, R. M. (2013). Kinetics of carotenoids degradation and color change of pequi oil submitted to heating at frying temperature. Ciência Rural, 43(8), 1509-1515. https://doi.org/10.1590/S0103-84782013000800027

Rodriguez-Amaya, D. B. (2008). Fontes brasileiras de carotenóides: Tabela brasileira de composição de carotenóides em alimentos. Brasília: MMA/SBF. Retrieved from https://www.mma.gov.br/estruturas/ sbf_agrobio/_publicacao/89_publicacao09032009113306.pdf

Salas-Salvadó, J., Casas-Agustench, P., Murphy, M. M., López Uriarte, P., \& Bulló, M. (2008). The effect of nuts on inflammation. Asia Pac J Clinical Nutr., 17(Suppl. 1), 333-336.

Santos, R. D., Gagliardi, A. C. M., Xavier, H. T., Magnoni, C. D., Cassani, R., Lottenberg, A. M. P., ... Ramos, S. (2013). I Diretriz sobre o consumo de gorduras e saúde cardiovascular. Arq. Bras. Cardiol., 100(1), 1-40. https://doi.org/10.5935/abc.2013S003

Schmidt, S., \& Pokorny, J. (2005). Potential application of oilseeds as sources of antioxidants for foo lipids-A review. Czech Journal of Food Science, 23(3), 93-102. https://doi.org/10.17221/3377-CJFS

Silva, M. L. C., Costa, R. S., Santana, A. S., \& Koblitz, M. G. B. (2010). Phenolic compounds, carotenoids and antioxidant activity in plant products. Semina: Ciências Agrárias, 31(3), 669-682. https://doi.org/10.5433/ 1679-0359.2010v31n3p669

Simopoulos, A. P. (2004). Omega-6/omega-3 essential fatty acid ratio and chronic diseases. Food Reviews International, 20, 77-90. https://doi.org/10.1081/FRI-120028831

TACO. (2011). Tabela Brasileira de composição de alimentos (4th ed.). Campinas: NEPA-UNICAMP, Brazil. Retrieved from https://www.cfn.org.br/wpcontent/uploads/2017/03/taco_4_edicao_ampliada_e_revisada.pdf

Tapsell, L. C., Gillen, L. J., Patch, C. S., Batterham, M., Owen, A., Baré, M., \& Kennedy, M. (2004). Including walnuts in a low-fat/modified-fat diet improves HDL cholesterol-to-total cholesterol ratios in patients with type 2 diabetes. Diabetes Care, 27(12), 2777-2783. https://doi.org/10.2337/diacare.27.12.2777

Thomazella, M. C., Góes, M. F., Andrade, C. R., Debbas, V., Barbeiro, D. F., Correia, R. L., ...Laurindo, F. R. (2011). Effects of high adherence to mediterranean or low-fat diets in medicated secondary prevention patients. Am. J. Cardiol., 108(11), 1523-1529. https://doi.org/10.1016/j.amjcard.2011.07.008

Uenojo, M., Maróstica Junior, M. R., \& Pastore, G. M. (2007). Carotenoids: properties, applications and biotransformation in flavor compounds. Quim. Nova, 30(3), 616-622. https://doi.org/10.1590/S0100-40422 007000300022

Vaz, J. S., Deboni, F., Azevedo, M. J., Gross, J. L., \& Zelmanovitz, T. (2006). Ácidos graxos como marcadores biológicos da ingestão de gorduras em alimentos. Revista de Nutrição, 19(4), 489-500. https://doi.org/ $10.1590 / \mathrm{S} 1415-52732006000400008$

Venkatachalam, M., \& Sathe, S. K. (2006). Chemical composition of selected edible nut seeds. Journal of Agricultural and Food Chemistry, 54(13), 4705-4714. https://doi.org/10.1021/jf0606959 
Vignini, A., Alidori, A., Montesi, L., Raffaelli, F., Nanetti, L., Bertoli, E., \& Mazzanti, L. (2011). Vitamin E, diabetes and related diseases: An update. Mediterr. J. Nutr. Metab., 4(1), 3-9. https://doi.org/10.1007/ s12349-010-0006-y

Wellen, K. E., \& Hotamisligil, G. S. (2005). Inflammation, stress, and diabetes. J. Clin. Invest., 115(5), 1111-1119. https://doi.org/10.1172/JCI25102

WHO (World Health Organization). (2011). Noncommunicable diseases country profiles. Geneva.

WHO (World Health Organization). (2013a). Health topics: Chronic diseases. Geneva. Retrieved from http//www.who.int/topics/chronic_diseases/en

WHO (World Health Organization). (2013b). Health statistics and information systems-Projections of mortality and causes of death, 2015 and 2030. Geneva. Retrieved from http://www.who.int/healthinfo/global burden_disease/projections/en

WHO (World Health Organization). (2017). Cardiovascular diseases. Geneva. Retrieved from https://www.paho. org/bra/index.php?option=com_content\&view=article\&id=525:doencas-cardiovasculares\&Itemid=1096

Xiao, C., Giacca, A., Carpentier, A., \& Lewis, G. F. (2006). Differential effects of monounsaturated, polyunsaturated and saturated fat ingestion on glucose-stimulated insulin secretion, sensitivity and clearance in overweight and obese, non-diabetic humans. Diabetologia, 49(6), 1371-1379. https://doi.org/ $10.1007 / \mathrm{s} 00125-006-0211-\mathrm{x}$

Yang, J. (2009). Brazil nuts and associated health benefits: A review. Food Sci. Tecnol., 42, 1573-1580. https://doi.org/10.1016/j.lwt.2009.05.019

Yang, J., Liu, R. H., \& Halim, L. (2009). Antioxidant and antiproliferative activities of common edible nut seeds. Food Sci Technol., 42, 1-8. https://doi.org/10.1016/j.lwt.2009.05.019

Zimmermann, A. M., \& Kirste, V. R. (2008). Alimentos com função antioxidante em doenças crônicas: uma abordagem clínica. Disc. Scientia., 9(1), 51-68.

\section{Copyrights}

Copyright for this article is retained by the author(s), with first publication rights granted to the journal.

This is an open-access article distributed under the terms and conditions of the Creative Commons Attribution license (http://creativecommons.org/licenses/by/4.0/). 